\title{
Rastlantısal Olarak HBsAg Pozitifliği Saptanan Hastalarda Karaciğer Hastalığının Irdelenmesi
}

\author{
Determination of Liver Disease in Incidentally Detected HBsAg Positives
}

\author{
Hilal DAĞTEKIN1, Fehmi TABAK1, Bilgül METE1, Abdullah SONSUZ2, Ali MERT2, Reşat ÖZARAS1, \\ Neşe SALTOĞLU1, Recep ÖZTÜRK1 \\ 1/istanbul Üniversitesi Cerrahpaşa Tıp Fakültesi, Enfeksiyon Hastalıkarı Anabilim Dalı, Istanbul, Türkiye \\ 2Istanbul Üniversitesi Cerrahpaşa Tıp Fakültesi, Iç Hastalıkları Anabilim Dalı, Gastroenteroloji Bilim Dalı, Istanbul, Türkiye
}

\begin{abstract}
ÖZT
Amaç: Rastlantısal olarak HBsAg pozitifliği saptanan hastalarda karaciğer hastalı̆ııın irdelenmesi.

Gereç ve Yöntemler: Rastlantısal olarak HBsAg pozitifliği saptanan (kan bağışı, ameliyat öncesi, evlilik öncesi, check up, aile taraması, gebelik, iş yeri ve spor merkezlerine başvuru vb.) 267 hasta çalışmaya dahil edildi. HBsAg pozitifliği ile birlikte biyokimyasal değerlendirme yapılarak başvuran hastalar çalışmaya alınmadı. Hastalar biyokimyasal, serolojik test sonuçları, histopatolojik ve klinik bulgularılla birlikte değerlendirildi.

Bulgular: Hastaların $192(\% 71,9)$ 'si erkek, $75(\% 28,1)$ 'i kadındı. lki yüz krrk beş $(\% 92,1)$ hasta HBeAg negatifken, 21(\%7,9) hasta HBeAg pozitifti. Hastaların 153 $(\% 57,3)$ 'ünde HBV-DNA $\leq 2000 \mathrm{IU} / \mathrm{ml}$ iken $114(\% 42,7)$ 'ünde HBV-DNA >2000 $\mathrm{IU} / \mathrm{ml}$ idi. Elli beş hastaya karaciğer biyopsisi yapıldı. Bu hastaların 34'ünde fibroz skoru $\geq 2,11^{\prime}$ inde HAl $\geq 8$ idi. Biyopsi yapılan ve yapılamayan tüm hastalar değerlendirildiğinde sekizi siroz olmak üzere toplam 37 (30'u HBeAg negatif, 7'si HBeAg pozitif) hasta tedavi endikasyonu olan kronik hepatit B (KHB), yedi hasta immuntoleran dönemde KHB, $158(\% 59,1)$ hasta ise inaktif taşıııı tanısı aldı. Sirotik hastalardan birinde hepatosellüler kanser (HSK) saptandı.

Sonuç: Biyopsi yapılan hastaların ALT ve HBV-DNA değerleri göz önüne alındığında heterojen bir grup olduğu söylenebilir. Bunlar göz önüne alındığında biyopsi yapılamamış 58 hastaya da biyopsi yapılsaydı, biyopsi yapılan 55 hasta ile birlikte değerlendirildiğinde hastaların yarısından fazlasının inaktif taşıyıcı, en az 1/4'ünün KHB tanısı alacağı düşünülebilir. (Viral Hepatit Dergisi 2012; 18(2): 52-6)
\end{abstract}

Anahtar Kelimeler: Rastlantısal HBsAg pozitifliği, inaktif taşıyıcı, kronik hepatit B

\begin{abstract}
Objective: To assess the grade of underlying liver disease in incidentally detected asymptomatic HBsAg positive subjects (IDAHS).

Materials and Methods: We examined 267 IDAHS (preoperative, pregnancy, blood donor, family and premarital screenings, check-up.. ). The patients whose HBsAg positivity and biochemical parameters studied together were excluded. Clinical, biochemical, virological and histological assessments were performed. Results: One hundred and ninety two $(71.9 \%)$ of the patients were male and $75(28.1 \%)$ of them were female. Two hundred and forty five $(92.1 \%)$ subjects were HBeAg negative and $21(7.9 \%)$ were HBeAg positive. HBV-DNA levels were $<2000$ $\mathrm{IU} / \mathrm{ml}$ in $57.3 \%$ of the patients whereas $42.7 \%$ of them had a HBV-DNA level of $\geq 2000 \mathrm{IU} / \mathrm{mL}$. Thirty four of 49 patients having biopsy had significant fibrosis ( $\mathrm{F} \geq 2)$ and 11 of patients had a histological activity index of $\geq 8$. Taking into account all patients with and without biopsy 37 of them took diagnosis of therapy indicated chronic hepatitis B (8 of them were cirrhosis). One hundred and fifty eight (59,1\%) and seven patients were diagnosed as inactive carriers and immuntolerant respectively. One of the cirrhotic patients had hepatocellular carcinoma. Forty six cases who were diagnosed neither as CHB nor as inactive carrier (with HBV-DNA level $\geq 2000 \mathrm{lU} / \mathrm{ml}$ and normal ALT) were planned to be followed up.

Conclusion: Taking into account the heterogenicity and distribution of the patients having biopsy according to their ALT and HBV-DNA levels; if we could have made biopsy for all of the 113 patients ( 55 with biopsy, 58 without biopsy) at least a quarter of patients could have taken diagnosis of $\mathrm{CHB}$ and more than half of the patients could be categorized as inactive carrier. (Viral Hepatitis Journal 2012; 18(2): 52-6)
\end{abstract}

Key words: Incidentally detected HBsAg positivity, inactive carrier state, chronic hepatitis B

Yazışma Adresi/Address for Correspondence: Dr. Fehmi Tabak, Istanbul Üniversitesi Cerrahpaşa Tıp Fakültesi, Enfeksiyon Hastalıkları Anabilim Dalı, Istanbul, Türkiye Gsm.:+90 5336207022 E-mail: fehmitabak@yahoo.com

Received/Geliș tarihi: 24.09.2012 Accepted/Kabul tarihi: 25.09.2012 


\section{Giriş}

Her yıl 500 milyondan fazla insan hepatit B virusu (HBV) ile karşılaşmaktadır (1). Tüm dünyada yaklaşık 2 milyar insanın HBV enfeksiyonu geçirdiğini gösteren serolojik bulguları olduğu tahmin edilmektedir $(2,3)$. Tüm dünyada 1982 yılından beri yüksek etkinlikli aşıların kullanılmasına rağmen her yıl 1 milyondan fazla insan kronik HBV enfeksiyonu ve komplikasyonları nedeniyle ölmektedir. Kronik HBV enfeksiyonu HBsAg pozitifliğinin 6 aydan uzun süre devam etmesini tanımlamakta olup, asemptomatik taşıyıcılıktan siroza kadar geniş bir hastalık spektrumu içinde görülebilmekte ve karaciğer yetmezliği, hepatoselüler karsinoma (HSK) gibi önemli komplikasyonlara yol açabilmektedir.

Türkiye, HBsAg prevalansı açısından orta endemik ülkeler arasında (\%2-7) yer alır. Bu sınıflandırmada HBsAg ve anti-HBs pozitifliği, en sık bulaşma yolu ile hastalığın edinildiği yaş göz önüne alınır. Ülkemizde HBsAg prevalansı son yıllardaki sosyoekonomik durumdaki kısmi düzelme, hijyen koşullarının iyileştirilmesi, 1998 yılından itibaren ulusal bebeklik rutin aşı programına Hepatit B aşısının alınması sonucunda \%5'ten \%34'lere inmiştir (4). HBsAg taşıyıcılarının ayrıntılı incelemelerinde bu kişiler inaktif taşıyıcı, kronik hepatit $B$, siroz veya karaciğer kanseri olarak değerlendirilir. Bu olguların çoğu inaktif taşıyıcı olup, bir bölümü de tedavi gereksinimi olan kronik hepatitli hastalardır.

\section{Gereç ve Yöntemler}

Otuz bir aylık süreçte bu kritere uyan 267 (\%72'si erkek, \%28'i kadın) çalışmaya dahil edildi. Mart 2009 ve Eylül 2011 tarihleri arasında başvuran, rastlantısal olarak evlilik öncesi, ameliyat öncesi, kan bağışı, gebelik veya aile taraması sırasında yapılan serolojik kontroller sırasında ilk kez HBsAg pozitifliği saptanan ve hiçbir değerlendirme yapılmadan hastanemize başvuran hastalarda ilk başvuru anındaki kronik HBV enfeksiyonunun klinik formunu belirlemeye yönelik ileriye dönük bir çalışma yaptık.

\section{Bulgular}

Çalışma sonucunda HBsAg pozitifliği, olguların 103(\%38,6)'ünde kan bağışı, 66(\%24,7)'sında check-up, 30 $(\% 11,2)^{\prime}$ unda ameliyat öncesi değerlendirme, 23(\%8,6)'ünde evlilik öncesi taramalar, 21(\% 7,9)'inde aile taraması, 24(\%9)'ünde ise diğer taramalar (gebelik, iş yeri ve spor merkezlerine başvuru) sırasında saptandı.

Saptanma şekline göre hastaların dağılımı Tablo 1'de özetlenmiştir.

HBV-DNA düzeyi bakılan 267 hastanın 153 (\%57,3)'ünde HBV-DNA 2000 IU/mL'nin altında, 114 (\%42,6)'ünde 2000 IU/mL'nin üstünde idi. Yirmi üç $(\% 8,6)$ hastada HBV-DNA saptanmadı. On yedi $(\% 6,3)$ hastada ise HBV-DNA $>110.000 .000 \mathrm{IU} / \mathrm{mL}$ idi. HBeAg'si bakılan 266 hastanın 245 $(\% 92,1)^{\prime}$ inde HBeAg negatif iken, $21(\% 7,9)^{\prime}$ 'inde HBeAg pozitif bulundu. HBV-DNA $<2000 \mathrm{IU} / \mathrm{mL}$ olan hastalarda ortalama ALT değerinin $37,4(S D \pm 46,9)$ iken HBV-DNA'sı $\geq 2000 \mathrm{IU} / \mathrm{mL}$ olan hastalarda 41,9 (SD \pm 56$)$ olduğu görüldü.
Karın USG kontrolü yapılan 199 hastanın 125 (\%62,8)'inde patolojik bulguya rastlanmadı. Patolojik bulgu saptanan hastaların 24 (\%12)'ünde grade 1, $31(\% 15,5)$ 'inde grade 2, 11 $(\% 5,5)$ 'inde grade 3 hepatosteatoz, $5(\% 2,5)$ hastada splenomegali saptandı. Ayrıca 5 hastada karaciğer sirotik görünümlüydü. Sirotik hastalardan üçünde splenomegali, birinde ise hepatosellüler karsinom ile uyumlu lezyon saptandı. Hiçbir hastada asit görülmedi.

Hastaların 55 (\%20,5)'ine perkütan karaciğer biyopsisi yapıldı. Karaciğer biyopsi materyalleri 49 hastada histopatolojik olarak Ishak skorlamasına göre değerlendirildi. HBV-DNA'sı $<2000 \mathrm{IU} / \mathrm{mL}$ olan 2 hastadan birinin biyopsisinde buzlu cam görünümü ve nadir fokal nekroz, diğerinde ise hafif enflamasyon ve hafif fibroz saptandı ancak bu hastanın yapılan klinik ve laboratuvar değerlendirmelerinde siroz olduğu görüldü. Bir hastada kronik hepatit B ile uyumlu bulgular vardı. Iki hastanın biyopsi materyali histopatolojik değerlendirme için yetersiz iken bir hastada ise hepatit bulgusuna rastlanmadı.

Hastalar yapılan klinik, histopatolojik incelemeler, görüntüleme ve laboratuvar parametreleri ile birlikte değerlendirilerek inaktif $\mathrm{HBsAg}$ taşıyıcısı, immuntoleran, kronik hepatit B, siroz ve HSK tanıları aldı. Bir grup hasta ise değişik nedenlere bağlı olarak değerlendirilemeyen hasta grubu olarak adlandırıldı.

Biyopsi yaptığımız 55 hastanın 34'ü KHB, 14'ü inaktif taşıyıcı, ikisi immuntoleran dönemde KHB tanısı aldı. Klinik ve labarotuvar parametreleri ile siroz tanısı alan üç hasta ile birlikte değerlendirildiğinde toplamda sekizi siroz olmak üzere 37 hasta tedavi gereksinimi olan KHB tanısı alırken, 158 hasta ise inaktif taşıyıcı tanısı aldı. Kronik hepatit B tanısı alan otuz yedi hastanın 30(\% 81,1)'u HBeAg negatif iken 7(\%18,9)'si HBeAg pozitif idi.

Biyopsi yapılamayan 212 hastanın olguların 144(\%67,9)'ü klinik ve laboratuvar tetkikleri sonucunda inaktif taşıyıcı olarak değerlendirildi. Bu grubun dışında kalan 58 hastanın 12'sinde HBV-DNA $\geq 2000 \mathrm{IU} / \mathrm{mL}$ ve ALT değerleri yüksek idi. ALT değerleri normal ve HBV-DNA $\geq 2000 \mathrm{IU} / \mathrm{mL}$ olan 46 hastadan 19'unda HBV-DNA $\geq 20,000 \mathrm{IU} / \mathrm{mL}, 27$ 'sinde ise HBV-DNA 2000-19.999 IU/mL idi. Bu hastaların hepsi HBeAg negatif idi. Biyopsi yapılmayan hastalardan HBV-DNA $<2000 \mathrm{IU} / \mathrm{mL}$ olan, ALT değerleri 1-3 kat yüksek seyreden 9 hastadan 5'ine karın USG yapıldı, bir hastada grade 1 steatoz saptanırken diğerlerinde herhangi bir patolojiye rastlanmadı. Bu hastalar çalışmada inaktif taşyıcı grubuna dahil edilerek takibe alındı. HBeAg pozitif olan, ALT değerleri normal ve HBV-DNA değerleri sırasıyla $753 \mathrm{IU} / \mathrm{mL}$ ve $23 \mathrm{lU} / \mathrm{mL}, 393 \mathrm{lU} / \mathrm{mL}$ olan 3 hasta, biyopsisi yapılan ancak Ishak skorlaması yapılmamış hastalar,

Tablo 1. Saptanma şekline göre hastaların dağııımı

\begin{tabular}{lcc}
\hline Saptanma Şekli & Hasta Sayısı & $\%$ \\
\hline Kan bağışı & 103 & 38,6 \\
Check-up & 66 & 24,7 \\
Ameliyat öncesi değerlendirme & 30 & 11,2 \\
Evlilik öncesi tarama & 23 & 8,6 \\
Aile Taraması & 21 & 7,9 \\
Diğer (gebelik, iş yeri ve spor merkezlerine başvuru) & 24 & 9
\end{tabular}


HBV-DNA $\geq 2000 \mathrm{IU} / \mathrm{mL}$ olan ancak biyopsisi yapılamamış hastalar değerlendirilemeyen hasta grubuna dahil edildi.

HBeAg pozitif hastalardan sekiz hastanın (\%38) kronik aktif hepatit B olduğu saptandı. ortalama fibroz skoru 2, ortalama HAl değeri ise 7 olarak hesaplandı.

$\mathrm{HBeAg}$ negatif hastaların ortalama fibroz skoru 2 (sınırlar: 06), ortalama HAl değeri ise 5 (sınırlar: 2-12) idi. Yirmi yedi $\mathrm{HBeAg}$ negatif hasta histopatolojik olarak kronik aktif hepatit B tanısı aldı (fibroz skoru $\geq 2$ ).

HBV-DNA'sı <2000 IU/mL olan 3 hastaya yapılan karaciğer biyopsisinin histopatolojik değerlendirmesinde ortalama HAl değeri 3, fibroz skoru ise 2 olarak hesaplandı.

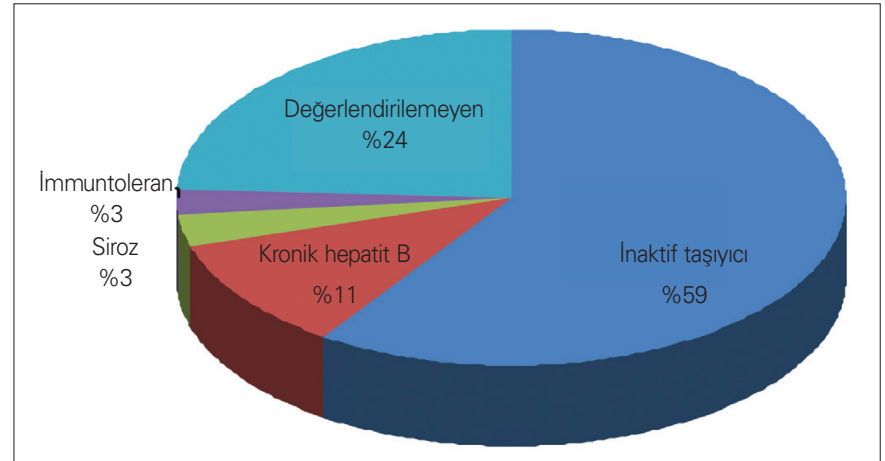

Tablo 2. Rastlantısal olarak HBsAg pozitifliği saptanan hastaların tanısal dağııımı

Tablo 3. Biyopsi yapılan hastaların HBV-DNA değeri, HBeAg serolojisi, HAI ve fibroz skoruna göre dağı̆ımı

\begin{tabular}{lc}
\hline Parametre & $\mathbf{n}(\%)$ \\
\hline HBV-DNA $<2000 \mathrm{IU} / \mathrm{mL}$ & $5(\% 9)$ \\
HBV-DNA $\geq 2000 \mathrm{IU} / \mathrm{mL}$ & $50(\% 91)$ \\
$\mathrm{HBeAg}(+)$ & $10(\% 18)$ \\
$\mathrm{HBeAg}(-)$ & $45(\% 82)$ \\
$\mathrm{HAI}<8$ & $38(\% 77,5)$ \\
$\mathrm{HAI} \geq 8$ & $11(\% 22,5)$ \\
Fibroz skoru $<2$ & $15(\% 30,6)$ \\
Fibroz skoru $\geq 2$ & $34(\% 69,4)$ \\
\hline
\end{tabular}

Tablo 4. Sadece AASLD kriterleri göz önüne alınarak yapılan hasta dağı̆ımı

\begin{tabular}{lc}
\hline & Olgu sayısı (n) \\
\hline Kronik hepatit B & 20 \\
Inaktif taşıyıcı & 140 \\
Immuntoleran dönemde KHB & 8 \\
Tedavi kararı için izlenmesi ve/veya biyopsi yapılması önerilenler & 99 \\
• Biyopsi önerildiği halde yapılamayanlar & 13 \\
• HBeAg (-), HBV-DNA $\geq 20000$ IU/mL, ALT 1-2 kat & 13 \\
• HBeAg (-), HBV-DNA $\geq 20000$ IU/mL, ALT normal seyreden & 31 \\
• HBeAg(-), HBV-DNA 2000-20000 IU/mL, ALT normal seyreden & 38 \\
• Biyopsisi Ishak skorlamasına göre değerlendirilmeyen & 1 \\
• HBeAg (+) olan HBV-DNA değerleri & 3 \\
sırasıyla 753, 23, 393 IU/mL olan &
\end{tabular}

HBV-DNA'sI $\geq 2000 \mathrm{IU} / \mathrm{mL}$ olan 46 hastada saptanan ortalama HAl değeri 5 iken ortalama fibroz skoru 2 olarak hesaplandı. HAl'si $<8$ olan hastalardaki ortalama ALT 64 iken HAl'si $\geq 8$ olanlarda 71 olarak hesaplandı. Fibroz skoru $<2$ olan hastalarda ortalama ALT 44; fibroz skoru $\geq 2$ olanlarda ise ortalama ALT değeri 75 idi.

On bir hastada fibroz skoru $\geq 2$ ve $\mathrm{HAl} \geq 8$ olarak saptandı. Üç hasta $\mathrm{HBeAg}$ pozitif, sekiz hasta ise $\mathrm{HBeAg}$ negatifti. ALT ortalama değeri 71 (ALT aralığı:17-254) olarak saptandı. HBVDNA ortalama değeri 37.559.000 IU/mL (HBV-DNA aralığı: 2846-146.000.000 IU/mL) (SD $\pm 55.877 .900)$.

Hastalardan sekizinin yapılan tetkikler sonucunda ilk tanı anında sirotik olduğu, hastalardan bir tanesinin de HSK olduğu görüldü.

Histopatolojik değerlendirme sonucunda kronik hepatit B olarak değerlendirilen 34 hastanın 2(\%3,6)'sinin HBV-DNA'sı $<2000 \mathrm{IU} / \mathrm{mL}, 32(\% 58,1)$ 'sinin ise HBV-DNA'sı $\geq 2000 \mathrm{IU} / \mathrm{mL}$ idi.

Tüm olgular, American Association for the Study of Liver Diseases (AASLD) (5) rehberi önerilerine göre değerlendirildiğinde $\mathrm{HBeAg}$ pozitif hastalardan ALT değeri üst sınırın $\geq 2$ katı, HBV-DNA $\geq 20.000 \mathrm{IU} / \mathrm{mL}$ olan 13 hasta (4 $\mathrm{HBeAg}$ pozitif, $9 \mathrm{HBeAg}$ negatif) karaciğer biyopsisinin hekimin tercihine bağlı olduğu grubu oluşturmaktaydı. Bu gruptan 3'ü HBeAg pozitif, 4'ü HBeAg negatif olmak üzere toplam 7 hastaya karaciğer biyopsisi yapıldı. Histopatolojik değerlendirme sonucunda 6 hasta tedavi endikasyonu olan kronik hepatit B tanısı aldı. Bir hastada ise biyopsi materyali yetersiz idi. Beşi $\mathrm{HBeAg}$ negatif olan diğer altı hastaya ise biyopsi yapılamadı.

HBeAg pozitif, HBV-DNA $\geq 20000 \mathrm{IU} / \mathrm{mL}$ olan, takiplerinde ALT değerleri 1-2 kat yüksek seyreden ve AASLD rehberinde de karaciğer biyopsisi yapılması önerilen bu gruba uyan 7 hastadan 5 'ine karaciğer biyopsisi yapıldı. Üç hasta kronik hepatit B tanısı alırken, 2 hastaya immuntoleran dönemde KHB tanısı koyularak izleme alındı. ALT değerleri normal, HBV-DNA $\geq 20000 \mathrm{IU} / \mathrm{mL}$, yaş >40 olan bir hastaya yine AASLD önerileri göz önüne alınarak karaciğer biyopsisi yapıldı ve hastaya kronik hepatit $B$ tanısı koyuldu. HBeAg pozitif olan yüksek viral yükü olan ve takiplerinde ALT değerleri normal, yaşları <30 olan 5 hasta ise biyopsi yapılmadan immuntoleran kabul edilerek takibe alındı. Bir yıllık takibinde ALT değerleri normal seyreden 22 yaşında, HBV-DNA $\geq 110.000 .000 \mathrm{IU} / \mathrm{mL}$ olan bir hastaya dış merkezde karaciğer biyopsisi yapılmış. Histopatolojik değerlendirme sonucunda hasta KHB tanısı almıştır.

AASLD rehberinde HBeAg negatif, HBV-DNA $\geq 20000$ $\mathrm{IU} / \mathrm{mL}$, ALT normal veya 1-2 kat yüksek seyreden hasta grubuyla ilgili herhangi bir öneri bulunmamaktadır. Bu grupta yer alan 44 hastadan 21'ine karaciğer biyopsisi yapıldı. Bu hastalardan 16'sı kronik hepatit B, 5'i inaktif taşıyıcı tanısı aldı. Bir hastanın ise laboratuvar ve görüntüleme tetkikleri sonucunda siroz olduğu anlaşıldı.

HBeAg negatif olup HBV-DNA 2000-20000 IU/mL olan ALT 1-2 kat yüksek seyreden ve AASLD rehberine göre ALT yüksekliğinin sebat etmesi durumunda biyopsi önerisi alan 5 hastadan 3'üne biyopsi yapıldı. Üç hasta da inaktif taşıyıcı olarak değerlendirildi. HBV-DNA 2000-20000 IU/mL olan ve ALT normal seyreden, AASLD'de takip edilmesi önerilen 38 hastadan 12'sine karaciğer biyopsisi yapıldı. Altı hasta kronik hepatit B, 5 hasta inaktif taşıyıcı tanısı aldı. Bir hastada ise alınan 
karaciğer dokusunun inceleme için yetersiz olduğu belirtildi. HBV-DNA <2000 IU/mL olan ALT 1-2 kat yüksek seyreden ve bu yüksekliğin sebat etmesi durumunda AASLD tarafından karaciğer biyopsisi yapılması önerilen $13 \mathrm{HBeAg}$ negatif hastanın 3'üne biyopsi yapıldı. Bir hasta kronik hepatit B tanısı aldı. Bir hastanın biyopsi materyalinde buzlu cam, nadir fokal nekroz, bir hastada ise hafif fibrozis, hafif enflamasyon saptandı. Ancak bu hasta klinik ve laboratuvar değerleriyle birlikte değerlendirildiğinde siroz olarak kabul edildi. Bu gruptan bir hastaya ise hepatosellüler karsinom tanısı koyuldu. Yüz otuz yedi hasta ise AASLD rehberi kriterlerine (ALT normal seyreden, HBV-DNA <2.000 IU/mL) uygun olarak inaktif taşıyıcı tanısı aldı.

Sonuç olarak AASLD rehberinde tedavi için izlem ve/veya karaciğer biyopsisi önerilen gruplar değerlendirildiğinde 82 hastadan 33'üne karaciğer biyopsisi yapıldı. Biyopsi yapılmayan hastalardan biri siroz tanısı aldı. Yirmi iki hasta kronik hepatit B (\%26,8), 10 hasta inaktif taşıyıcı olarak değerlendirildi. Çalışmaya dahil edilen hastalardan 13'ü AASLD rehberine göre biyopsi gereksinimi olmadan tedavi alabilecek durumda idi.

\section{Tartıșma}

Rastlantısal olarak HBsAg pozitifliği saptanan hastalar ile ilgili çalışmalar irdelendiğinde, Mukhopadhya ve ark.'nın bir çalışmasında 5'i HBeAg pozitif olan 43 hastaya karaciğer biyopsisi yapılmış, biyopsi örnekleri Ishak skorlamasına göre değerlendirilmiştir. HBV-DNA değerleri kalitatif olarak değerlendirilmiş. HBV-DNA'sı negatif veya pozitif olan tüm hastalarda $\mathrm{HAl}<3$ olarak saptanmıştır. On yedi hastada ise hepatosteatoz görülmüştür (6). Bir başka çalışmada ise aynı özelliklere sahip 29 hastaya karaciğer biyopsisi yapılmış, 8'i HBeAg pozitif olan 15 hastada $(\% 51,7) \mathrm{HAl}>3$ olarak saptanmış ve hastalar KHB olarak kabul edilmiştir. Bu çalışmada kronik hepatit B ile HBeAg serolojisi arasında bağlantı bulunamamıştır (7). Hindistan'da yapılmış bir diğer çalışmada rastlantısal olarak HBsAg pozitifliği saptanan 157 hastanın 92'sinde (\%59) HAl >3 olarak saptanmış, 48(\%52,1)'i HBeAg pozitif olan bu hastalar kronik hepatit olarak kabul edilmiştir. HBeAg (+) hastalar arasında $\mathrm{HAl}>3$ oranı $\mathrm{HBeAg}$ negatiflere göre istatistiksel olarak anlamlı derecede yüksek saptanmıştır (8). Her üç çalışmada da fibroz skoru değerlendirilmemiştir. Çalışma grubumuzda biyopsisi histopatolojik olarak değerlendirilebilen 49 hastanın ortalama HAl değeri 5, fibroz skoru ise 2 idi, tüm hastaların saptanabilir HBV-DNA değerleri vardı ve sadece 3 hastada histopatolojik olarak steatoz saptandı. Otuz dört hastada ise tedavi gereksinimi olan KHB tanısı koyuldu. Bu hastalardan 28'i HBeAg negatif, 6'sı HBeAg pozitifti. Hasta sayıları arasındaki belirgin farklılık nedeniyle istatistiksel olarak karşılaştırma yapmayı uygun bulmadık. Bizim çalışmamızda diğer çalışmalardan farklı olarak fibroz skorunu da göz önüne aldığımız düşünülürse yukarıdaki çalışmalarda yapıldığı gibi sadece $\mathrm{HAl}>3$ olan hastalar kronik hepatit B olarak kabul edilseydi biyopsi yapılan hastalar arasında KHB tanısı alan hastalarımızın oranının $(\% 69,3)$ düşeceği düşünülebilir.

Iki yüz altmış yedi hastamızın $158(\% 59,1)^{\prime}$ i inaktif taşıyıcı tanısı aldı. Mamun Al-Mahtab ve ark.'nın rastlantısal olarak HBsAg pozitifliği saptanan, HBV-DNA $<10.000$ kopya/mL olan ve ALT değerleri normal seyreden yani uluslararası rehberlere göre inaktif taşıyıcı tanısı alan ve düzenli olarak izlenmesi önerilen 141 hastaya biyopsi yaptıkları çalışmada hastaların \%56'sında histopatolojik olarak inaktif hepatit B saptanmıştır. Ancak hastaların \%11'inde ciddi fibrozis, \%26'sında ciddi enflamasyon saptanmıştır. On hastada ise hem ciddi fibrozis hem de enflamasyon saptanmıştır. Bu hastaların laboratuvar parametrelerine göre tamamen taşıyıcı gibi gözükse de aslında tedavi endikasyonu olan KHB hastaları olduğu saptanmıştır (9). Bir başka çalışmada ise benzer özelliklere sahip 157 hastanın $\% 41$ 'inde histopatolojik olarak inaktif taşıyıcılıkla uyumlu bulgular saptanmıştır (8). Fransa'da yapılan bir çalışmada ise 58 hastanın sadece \%9'unda Ishak skorlamasına göre fibroz skoru $\geq 2$ olarak değerlendirilmiştir (10). Biz de çalışmamızda saptanabilir HBV-DNA'sı olan her hastaya karaciğer biyopsisi yapmayı planlamıştık. Ancak hastaların bir bölümü karaciğer biyopsisinin yapılmasını istemediğinden bunu gerçekleştiremedik. Sadece biyokimyasal ve serolojik parametrelerle inaktif taşıyıcı tanısı alan hasta sayımız 144 idi. Mamun Al-Mahtab ve ark.'nın çalışmasının yapıldığı ülkedeki başlıca HBV bulaş yollarının ülkemizle benzer olmasını ve baskın genotipin Türkiye'deki gibi genotip D olduğunu göz önüne alırsak bizim de hastalarımıza biyopsi yapabilmemiz durumunda benzer oranlarda kronik hepatit B hasta sayısına ulaşabileceğimiz düşünülebilir.

Uluslararası rehberlerde ALT seviyeleri normal seyreden ve HBV-DNA $\geq 2000 \mathrm{lU} / \mathrm{mL}$ olan HBeAg negatif hastaların takibi konusunda net öneriler bulunmamaktadır. Bizim çalışmamızda ALT değerleri normal seyreden, HBeAg negatif, HBV-DNA değerleri ise 113-110.000.000 IU/mL olan, biyopsi yapılmış 25 hastanın \%56'sında tedavi gereksinimi olan KHB saptandı. Kumar ve arkadaşlarının yapmış olduğu bir çalışmada normal ALT değerine sahip, HBV-DNA $<100.000$ kopya/mL olan 116 hastanın yaklaşık \%21'inde HAl >3 (Knodell skorlamasına göre) saptanmış, bu hastaların da yarısında değişik oranlarda fibroz görülmüştür (11). Bu çalışmada HBV-DNA düzeyi ile histolojik değişiklikler arasında bir korelasyon olmadığı saptanmıştır. KHB tanısı alan hastalarımızın \%44'ünde ALT değerleri normal, HBVDNA $\geq 2.000 \mathrm{IU} / \mathrm{mL}$ idi. Lai ve arkadaşlarının yaptığı bir çalışmada ise HBV-DNA $\geq 10.000$ kopya/mL, ALT normal olan 59 hastanın \%37'sinde belirgin fibrozis veya enflamasyon olduğu görülürken (12), bir başka çalışmasında normal ALT ve yüksek HBV-DNA değerleri olan 57 hastanın \%24'ünde KHB saptanmış, bu çalışmada hastaların \%81'inde viral yük >105 kopya/mL olarak saptanmıştır (13). Bizim bu hasta grubunda KHB yüzdemiz yüksek çıkmıştır. Ancak Türkiye'de ve diğer birçok gelişmekte olan ülkede HBV ile karşılaşmanın daha çok yaşamın erken dönemlerinde olurken gelişmiş ülkelerde sıklıkla erişkin dönemde olduğu, dolayısıyla hastaların HBV ile enfekte kalma sürelerinin farkıı olduğu unutulmamalıdır. Aslında normal ALT değerleri, hepatitin olmadığını belirtmekten çok sadece mevcut tedavilere zayıf yanıt alınabileceğinin bir göstergesi olarak değerlendirilebilir (11).

Tsang ve ark. 5 yıllık retrospektif çalışmasında HBV-DNA $\geq 2.000 \mathrm{IU} / \mathrm{mL}$ ve HBeAg (-) olan ALT 1-2 kat yüksek seyreden 45 hastanın \%37,7'sinde, ALT > ×2 kat olan 81 hastanın \% 76,5'inde; HBeAg (+) olup ALT 1-2 kat yüksek seyreden 24 hastanın \%29'unda, ALT > ×2 kat olan 43 olgunun \%58,1'inde anlamlı histopatolojik bulgular saptanmış (Batts ve Ludwig skorlamasına göre fibroz skoru $\geq 2$ veya fibroz skoru $\geq 1$ ve $\mathrm{HAl}$ 
>2) (14). Bir Çin çalışmasında ise ALT <x2 kat seyreden 228 hastanın \%49,2'sinde belirgin enflamasyon, \%36,4'ünde belirgin fibrozis görülmüştür (15). Bizim çalışmamızda ise HBeAg (-) olup viral yükü $\geq 2.000 \mathrm{IU} / \mathrm{mL}$ olan, ALT 1-2 kat yüksek seyreden 36 hastanın \%63,8'inde, ALT >×2 olan üç hastada; HBeAg (+) olup ALT 1-2 kat yüksek seyreden iki hasta ile ALT $>\times 2$ kat olan üç hastada histopatolojik olarak KHB ile uyumlu bulgular saptandı. On iki hastamız ise ALT değerleri yüksek, HBV-DNA $\geq 2.000 \mathrm{IU} / \mathrm{mL}$ olduğu halde biyopsi yapılamadığı için değerlendirmeye alınamadı. Bizim ve benzer çalışmaların sonuçları ALT $<\times 2$ kat olan KHB hastalarında hastalığın şiddetini değerlendirmede en önemli metodun karaciğer biyopsisi olduğunu göstermektedir (16).

Papatheodoridis ve ark.'nın çalışmasında HBeAg negatif, ALT değerleri yüksek seyreden ve HBV-DNA $\geq 20.000 \mathrm{IU} / \mathrm{ml}$ olan 294 hastanın \%88,4'ünde histopatolojik olarak tedavi endikasyonu (Ishak skorlamasına göre HAl $\geq 7$ ve/veya fibroz skoru $\geq 2$ ) olan KHB saptanmıştır (16). Bizim grubumuzda ise benzer 16 hastanın \%68,7'sinde histopatolojik değerlendirme sonucunda tedavi endikasyonu olan KHB tanısı koyuldu. Aynı çalışmada HBV-DNA 2.000-19.999 IU/mL olan, 63 hastanın \%75'inde histopatolojik olarak tedavi endikasyonu olan KHB saptanırken çalışmamızda bu gruba ait sadece üç hastamız vardı. Üç hasta da inaktif taşıyıcı tanısı aldı. Gerek toplam gerekse biyopsi yapılabilen olgu sayımızın azlığı bu grupta hiç KHB tanılı hastamızın olmamasını açıklayabilir.

Son AASLD rehberinde kadınlarda ve erkeklerde ALT değerlerinde normalin üst sınırı sırasıyla $19 \mathrm{U} / \mathrm{L}$ ve $30 \mathrm{U} / \mathrm{L}$ olarak kabul edilmesinin eski sınırlara göre daha uygun olduğu belirtilmiştir (5). HBV-DNA $\geq 20.000 \mathrm{IU} / \mathrm{mL}$, ALT normal veya 1-2 kat yüksek seyreden, rehberlerde izlemleri konusunda net öneriler olmayan ancak bizim biyopsi yaptığımız hastalar bu değerlere göre tekrar değerlendirildiğinde üç hastanın biyopsi gereksinimi olmadan doğrudan tedavi alabilecek hasta olarak kabul edilebileceği görüldü. Ancak bu hastalardan birinin biyopsi materyalinin yapılan histopatolojik değerlendirmesi sonucunda inaktif taşıyıcı olduğu saptandı.

AASLD rehberinde tedavi için izlem ve/veya karaciğer biyopsisi önerilen gruplar değerlendirildiğinde 82 hastadan 33'üne karaciğer biyopsisi yapıldı. Biyopsi yapılmayan hastalardan biri siroz tanısı aldı. Yirmi iki hasta kronik hepatit B (\%26,8), 10 hasta inaktif taşıyıcı olarak değerlendirildi. Eğer 81 hastanın tamamına biyopsi yapılabilseydi $54(\% 66,6)$ hastanın kronik hepatit B tanısı alabileceği düşünülebilir.

\section{Sonuç}

Mevcut verilerle bir simülasyon çalışması yapıldığında; HBVDNA $\geq 2.000 \mathrm{lU} / \mathrm{mL}$, ALT değerleri normal seyreden 46 hasta ile yine $H B V-D N A \geq 2,000 \mathrm{IU} / \mathrm{mL}$ olan ALT değerleri yüksek seyreden 12 hastaya da biyopsi yapabilseydi, tüm olgularımızın yarısından fazlasının inaktif taşıyıcı, yaklaşık olarak \%25'inin KHB tanısı alabileceği düşünülebilir.

\section{Kaynaklar}

1. Koziel MJ, Siddıquı A. Hepatitis B virus and Hepatitis Delta Virus, Mandell GL, Bennett JE, Dolin R (eds). Principles of Infectious Diseases, 6th Ed, New York: Churchill Livingstone, 2005: 1864-90.

2. EASL international consensus conference on hepatitis B. The EASL jury. J Hepatol. 2009; 50: 227-42.

3. Fattovich G, Bartolotti F, Donato F. Natural history of chronic hepatits $\mathrm{B}$ : Special emphasis on disease progression and prognostic factors. J Hepatol. 2008; 48: 335-52.

4. Mıstık R. Türkiye'de Viral Hepatit Epidemiyolojisi-Yayınların Irdelenmesi. Tabak F, Balık I, Tekeli E (editörler) Viral Hepatit 2007; 9-50.

5. Lok AS, McMahon BJ. Chronic hepatitis B: Update 2009. Hepatology. 2009 ;50: 661-2.

6. Mukhopadhya A, Ramakrishna B, Richard V, Padankatti R, Eapen CE, Chandy GM. Liver histology and immunohistochemical findings in asymptomatic Indians with incidental detection of hepatitis B virus infection. Indian J Gastroenterol. 2006; 25: 128-31.

7. Dixit VK, Panda K, Babu AV, Kate MP, Mohapatra A, Vashistha P, et al. Asymptomatic chronic hepatitis B virus infection in northern India. Indian J Gastroenterol. 2007; 26: 159-61.

8. Chandra R, Kapoor D, Agarwal SR, Malhotra V, Sakhuja P, Sarin SK. Profile of asymptomatic chronic HBV infection in India. Indian J Med Res. 2002; 116: 50-7.

9. Al-Mahtab M, Rahman S, Akbar SMF, Kamal M, Khan MS. Clinical use of liver biopsy for the diagnosis and management of inactive and asymptomatic hepatitis B virus carriers in Bangladesh. J Med Virol. 2010; 82: 1350-4.

10. Martinot-Peignoux M, Boyer N, Colombat $M$, Akremi R, Pham BN, Ollivier $\mathrm{S}$, et al. Serum hepatitis B virus DNA levels and liver histology in inactive HBsAg carriers. J Hepatol. 2002; 36: 543-6.

11. Kumar M, Sarin SK, Hissar S, Pande C, Sakhuja P, Sharma BC, et al. Virologic and histologic features of chronic hepatitis B virus-ınfected asymptomatic patients with persistently normal ALT. Gastroenterology. 2008; 134: 1376-84.

12. Lai M, Hyatt BJ, Nasser I, Curry M, Afdhal NH. The clinical significance of persistently normal ALT in chronic hepatitis B infection. J Hepatol. 2007 ; 47: 760-7.

13. Lai $M$, Hyatt $B$, Afdhal $N$. Role of liver biopsy in patients with normal ALT and high HBV-DNA. Hepatology. 2005; 42: 720.

14. Tsang PS, Trinh H, Garcia RT, Pham JT, Ha NB, Nguyen $H$, et al. Significant prevalence of histologic disease in patients with chronic hepatitis B and mildly elevated serum alanie aminotransferase levels. Clin Gastroenterol Hepatol. 2008; 6: 569-74.

15. Chen EQ, Huang FJ, He LL, Bai L, Wang LC, Zhou TY, et al. Histological changes in chinese chronic hepatitis B patients with ALT lower than two times upper limits of normal. Dig Dis Sci. 2010; 55: 432-7.

16. Papatheodoridis GV, Manesis EK, Manolakopoulos S, Elefsiniotis IS, Goulis J, Giannousis J, et al. Is there a meaningful serum hepatitis B virus DNA cutoff level for therapeutic decisions in hepatitis B e antigen-negative chronic hepatitis B virus infection? Hepatology. 2008; 48: 1451-9 